\title{
More than marketised? Exploring the governance and accountability mechanisms at play in Social Impact Bonds
}

\author{
The published version of this paper is available at: \\ https://doi.org/10.1080/17487870.2019.1575736
}

Dr Eleanor Carter, Blavatnik School of Government, University of Oxford.

Email: Eleanor.carter@bsg.ox.ac.uk

\begin{abstract}
Social Impact Bonds are considered a highly marketised form of public service delivery and are understood to 'work' through the introduction of new capital into payment-by-results contracts. This paper, for the first time, connects findings from UK SIBs to evaluation of conventional payment-by-results contracts and the theoretical literature on governance and accountabilities. Markets and capital emerge as a potential red herring with hybridity of governance and the 'social' positioned as important dimensions facilitating qualitatively different services. This raises questions as to whether it is possible to extend SIBs, or whether increased scale and mainstream investors will dilute the 'SIB effect'.
\end{abstract}

\section{Keywords}

Social Impact Bonds; Social Investment; Public Services; Payment-by-results; Employment Support

\section{Acknowledgements}

The author wishes to thank participants at the conference on "Widening Perspectives on Social Impact Bonds" in London in September 2016 for their comments. I also wish to thank the Editor and three anonymous referees and for their comments.

\section{Policy highlights}

In the outsourced provision of public services commissioners and policymakers are increasingly making payment to independent provider organisations contingent on outcomes - the positive results that services produce in the lives of service users and citizens - rather than the volume or quality of outputs. 'Payment by Results' and 'Social Impact Bonds' are both examples of this trend.

In the UK, policy makers suggest that the introduction of a social investor and private capital enables voluntary sector organisations to take on back-ended PbR contracts but in practice the distinctions between SIBs and more conventional PbR models has been ambiguous.

This comparative study takes two British employment support programmes - which are implemented across the same time-frame; have overlap in participant characteristics; correspond in the type of service provider organisations; and where marketized logics of 'payment for outcomes' dominate - and uses detailed programmatic analysis to identify dominant accountability levers used to steer provider behaviours in each scheme.

Trust-led, relational 'network' governance comes to the fore as a potentially distinguishing, and arguably crucial, differentiator of SIBs.

\section{Introduction}

Public service commissioning and performance management systems have become increasingly focused on outcomes - the positive results that services produce in the lives of service users and citizens - rather than the volume or quality of outputs (Bovaird and Davies 2011). Social Impact Bonds (SIBs) are a particular form or 'sub-brand' of this outcomes-led approach and are surrounded by significant buzz: amongst protagonists SIBs are heralded as a mechanism to drive solutions to some of the most complex and expensive social problems (Roberts 2013). At its core, the SIB model applies non-governmental investment 
to the pursuit of social outcomes through a payment-by-results $(\mathrm{PbR})$ contract with services typically provided by social sector organisations.

As with other areas of outcome-based commissioning, the governance mechanisms and sets of accountability levers present within SIBs have received little by way of academic engagement, particularly in relation to the malleability and evolution of the approach. Descriptions of SIBs proffered by both practitioner and academic literatures describe the mechanism as a highly marketised form of service delivery. SIBs "monetize benefits of social interventions and tie pay to performance, limiting governmental control once the contract is designed" (Warner 2013, 303).

For proponents of the SIB approach, and PbR more broadly, it is the alignment of financial incentives, (explicitly linking a social target to financial success) that is understood as the mechanism through which perceived public sector shortcomings and inefficiencies can be overcome by introducing entrepreneurship and 'market discipline' (Fraser et al. 2016). The perceived innovation of the SIB approach - the introduction of a social investor and private capital to enable voluntary sector organisations to take on back-ended $\mathrm{PbR}$ contracts - emphasises financial logic as the 'fix'. Resistance to SIBs has equally pivoted around the market logic. Academic authors presenting a more 'cautionary narrative' (Fraser et al. 2016) have suggested that the marketised accountability levers of SIBs represent a further extension of neo-liberal logic in public policy making (Warner 2013) whereby communities and charitable endeavours are co-opted to the pursuit of financial gains for investors (Dowling and Harvie 2014).

With 45 SIBs now having been implemented in the UK and the dramatic scaling of international interest (Carter et al 2018; Gustafsson-Wright et al. 2015) it seems appropriate to develop a more critical empirical engagement with the governance and accountabilities at play within exemplars of the approach. This paper uses the concept of accountability to understand the interactions between multiple actors involved in public service delivery. Following Jantz et al. $(2015,5)$ accountability is understood as "a) a system of knowing and evaluating someone's behavior according to some standards and b) as a system of rewards or sanctions that are depending on these evaluations". Accountability relationships nestle as the institutional setting, encompassing a system of rules that structure the course of action available to, and chosen by, a set of actors, with specific levers dominating within particular governance regimes.

This paper questions the uncritical acceptance of SIBs as a project that can unambiguously be characterized as operating under a marketised governance framework. In doing so it makes two central contributions. Firstly, it extends previous work on accountability mechanisms by suggesting that each form of accountability lever has an overarching signature or 'footprint' that can be detected in the characteristics of programme delivery and the lived experience of programmes by participants. Accordingly, quantitative and qualitative material relating to perceptions of frontline staff-programme participant interactions can give important indications as to the essence and potential hybridity of accountabilities in practice. The second contribution is to situate, for the first time, empirical findings from the delivery of a large, national 'conventional' PbR scheme (the Work Programme) alongside a qualitative evaluation of SIBs as an alternative form of $\mathrm{PbR}$ (Innovation Fund). This comparative case analysis is particularly valuable, as employment support is the only policy area (to date) where a mainstream PbR scheme has been delivered in the same policy space, commissioned by the same authority (the British Department for Work and Pensions, DWP), with an overlapping cohort of participants and with a very similar outcome specification, to SIBs.

The case analysis indicates that there may be important distinctions between conventional PbR models and SIBs and teases out the additional, specific accountability arrangements that appear to be particular to SIBs. Though necessarily tentative given the early stage of SIB development, this is an important distinction, since - in the absence of a clear, bounded definition of SIBs - it is currently highly uncertain at what point SIBs end and mainstream PbR begins (Carter et al. 2018). Trust-led, relational 'network' governance comes to the fore as a potentially distinguishing, and arguably crucial, differentiator of SIBs. Markets and capital flows therefore surface as a potential red herring with hybridity of governance and the social emerging as important dimensions facilitating qualitatively different services. Such considerations will be critical in understanding whether it is possible, or desirable, to extend the approach, or whether increased scale and involvement of mainstream investors will dilute the 'SIB effect'. 
The remainder of the article is structured across three sections. Firstly, the full suite of accountability mechanisms available to social programmes is outlined alongside the likely 'signature' that each may leave at the front-line of lived programme experience. The second section describes the two case studies and their respective accountability arrangements. It synthesises empirical findings from a review of all sources describing service delivery and participant experiences under each scheme to assess the degree to which the signature of marketisation is detected. The final section reflects on the extent to which gaps within conventional accountability levers used to defend against perverse incentives within the SIB projects may have left a space for trust-based network accountabilities to grow.

\section{The suite of accountability dimensions}

The analytical framework of accountability mechanisms for unpacking the design and performance of social programmes is a potentially powerful lens but one that has yet to be formally applied to the understanding of SIBs. Building on the broader public service governance literature (Considine 2001; Bovaird and Löffler 2009) as well as the emerging literature which focuses specifically on accountability mechanisms in employment support (Jantz et al. 2015; Whitworth and Carter, 2017), five stylized overarching accountability mechanisms can be distilled, as summarized in Table 1.

\begin{tabular}{|c|c|c|c|c|c|}
\hline $\begin{array}{l}\text { Governance } \\
\text { type }\end{array}$ & $\begin{array}{l}\text { Source of } \\
\text { rationality }\end{array}$ & $\begin{array}{l}\text { Accountability } \\
\text { levers }\end{array}$ & Primary virtue & Service user - staff interaction & $\begin{array}{l}\text { Detectable 'signature' in the } \\
\text { characteristics of programme } \\
\text { experiences and outcomes }\end{array}$ \\
\hline Procedural & Law & Rules \& Regulations & Reliability & $\begin{array}{l}\text { 'Proceduralist' front-line staff follow rules and standardised } \\
\text { procedures. The same type and quantity of support is provided } \\
\text { regardless of participant characteristics. Those service users who can } \\
\text { benefit from these standardised approaches are supported but the } \\
\text { service is not tailored to individual user needs. A 'standardised service } \\
\text { to clients' is prioritised and there is little interest in output (or } \\
\text { outcome) measurement. }\end{array}$ & Standardised service and engagement \\
\hline Corporate & Management & $\begin{array}{l}\text { New Public } \\
\text { Management - } \\
\text { Plans, Targets \& } \\
\text { Monitoring }\end{array}$ & Goal-driven & $\begin{array}{l}\text { Frontline staff are clearly motivated by targets and plans for specified } \\
\text { 'client groups'. Process targets are actively pursued. Activities and } \\
\text { interventions are delivered 'to' relevant participants; outputs do not } \\
\text { necessarily align optimally to outcomes of interest, for example, } \\
\text { through the roll-out of training courses that do not necessarily lead to } \\
\text { jobs. }\end{array}$ & $\begin{array}{l}\text { Service activities are targeted to } \\
\text { prescribed participant groups but do not } \\
\text { respond to individual participant } \\
\text { characteristics }\end{array}$ \\
\hline Market & Competition & $\begin{array}{l}\text { Quasi-markets - } \\
\text { Prices \& } \\
\text { Competition }\end{array}$ & Cost-driven & $\begin{array}{l}\text { 'Marketised' frontline staff are sensitised toward and respond to the } \\
\text { costs and prices of different services and different service users. There } \\
\text { is a consciousness of the need to deliver 'payable outcomes' at the } \\
\text { lowest possible cost. }\end{array}$ & $\begin{array}{l}\text { Personalised services responsd to } \\
\text { participants and their context with the } \\
\text { targeting of services to those who are } \\
\text { most likely to achieve 'payable } \\
\text { outcomes' }\end{array}$ \\
\hline Democratic & $\begin{array}{l}\text { Democracy and } \\
\text { citizen preferences }\end{array}$ & $\begin{array}{l}\text { User choice and } \\
\text { voice }\end{array}$ & $\begin{array}{l}\text { Citizen- } \\
\text { driven/accountability }\end{array}$ & $\begin{array}{l}\text { Democratically engaged staff respond directly to the wishes and } \\
\text { ambitions of programme participants, designing services such that } \\
\text { provision is reviewed positively and will appeal to future participants. }\end{array}$ & $\begin{array}{l}\text { Service activities 'appeal' to a particular } \\
\text { client group and participants are } \\
\text { 'satisfied' though this may not directly } \\
\text { relate to improved performance or social } \\
\text { outcomes }\end{array}$ \\
\hline Network & Relationships/trust & $\begin{array}{l}\text { Trust, relationships, } \\
\text { and reputation }\end{array}$ & Flexibility & $\begin{array}{l}\text { Networkers base their work upon the co-production of results using } \\
\text { brokerage and holistic supports. A high value is "placed on trust and } \\
\text { maintaining good contacts with clients and other service providers" } \\
\text { (Considine, 2001: 34). }\end{array}$ & $\begin{array}{l}\text { Service activities 'wrap around' service } \\
\text { users responding flexibly to their needs } \\
\text { and ambitions by integrating a range of } \\
\text { relevant support services. This may } \\
\text { involve the 'coproduction' of outcomes. }\end{array}$ \\
\hline
\end{tabular}

Table 1: Accountability types. Adapted and extended from Considine 2001; Jantz et al 2015; Whitworth and Carter, 2017 
These five accountability dimensions can be understood as 'ideal types' each with distinctive reference points, rules, tactics and norms. Considine (2001) and others helpfully trace the evolution of these accountability levers, noting that the first three (procedural, corporate and marketised) broadly correspond to the development of public bureaucracy from its post war origins to more recent waves of 'reform'. The procedural captures 'old fashioned' notions of public bureaucracy with rule-based principles of reliability and procedural fairness. The plans and performance targets of corporate governance align with the rise of New Public

Management and respond to a perceived lack of responsiveness under traditional bureaucratic levers. More recently, the increased use of market-like methods is justified by claims that markets increase efficiency, efficacy and service responsiveness though in important ways, these are artificial 'quasi-marketised' creations. Democratic levers may draw on the 'topdown' accountability of electoral cycles (Jantz et al. 2015) or through the 'bottom-up' introduction of service user experience via levers of 'choice' (e.g. selection of provider/programme) and 'voice' (feedback and co-production) (Hirschman 1970). Importantly, in the field of employment support services and in SIBs more broadly, the userresponsiveness of service accountabilities is typically either largely or totally absent.

Network governance is an emerging accountability mechanism and represents more of an ideal or 'hypothetical' apparatus than a tangible approach in practice (Bovaird and Löffler 2009). The intention, under this idealized network conception of accountability, is that provision is coordinated across multiple, inter-dependent providers and agencies using relationships built on trust. Softer, informal levers are framed around co-operation and codependence with responsibilities shared across an inter-organisational web of public and private agencies.

Importantly, the core values and approaches associated with each of these accountability mechanisms are more than 'transitory rhetorical flourishes' but rather emerge as very real engagements enacted at the core of public services (Considine 2001, 18). The behaviour, relational dynamics and experiences of staff members, agencies, and crucially, service users are profoundly shaped by the degree to which differing combinations of accountability levers are leant on within any given programme. Any public programme on paper may incorporate elements from across each of these five accountability types (Whitworth and Carter, 2017) and in practice the degree to which the governance matrix - the respective mix and dominance of any one lever - may shore up or displace the ability for a programme to successfully deliver policymaker (or service user) ambitions.

Crucially, each of these accountability levers can be understood to tread down differently into the lived experience of programmes, leaving important, specific traces that can be used as signifiers of the dominant accountability mechanism (Table 1). Similar detectable signatures have been used by Considine (2001) to trace the temporal shifts of governance forms. In practice, hybridity across multiple governance types is a closer reflection of programme realities. In the early 2000s Considine (2001) noted an amalgamation of corporate and marketised levers in a 'corporate-market' type as the dominant model in front-line governance. This notion of hybridity offers something of an analogue to recent theoretical developments in the study of social enterprises - which although centred on organizational tropes - similarly emphasise the coming together of at least two different logics and value systems (Doherty et al 2014). These accountability signatures will be returned to as we consider empirical material related to the delivery of the two employment support cases. 
Firstly though, it is appropriate to introduce the Work Programme and Innovation Fund SIBs which have each been situated as exemplars of highly marketised accountabilities.

\section{The dominance of marketised accountabilities in UK employment support}

In the OECD context and particularly in the UK, there has been a clear progression in the degree to which successive welfare-to-work programmes have embraced marketization alongside 'work first' principles. The UK's flagship Work Programme for the long-term unemployed, launched in 2011, is understood as an international pioneer in the degree to which it is based on outsourcing, PbR and provider flexibility (Carter and Whitworth 2015). SIBs equally sit at the crest of this marketising agenda, framed as they are around the financial incentives of outcome-based contracts (see Table 2).

INSERT TABLE 2

\begin{tabular}{|c|c|c|}
\hline & Work Programme & Innovation Fund \\
\hline Programme objective & $\begin{array}{l}\text { Supporting people who are long-term } \\
\text { unemployed or at risk of becoming so (back) } \\
\text { into the labour market. To support more } \\
\text { participants into work, faster, for longer and } \\
\text { whilst reducing gaps in performance outcomes } \\
\text { between the easier- and harder-to-help. }\end{array}$ & $\begin{array}{l}\text { Supporting young people who are } \\
\text { disadvantaged, or at risk of disadvantage, to } \\
\text { participate and succeed in education or training } \\
\text { and thereby improve their employability, } \\
\text { reducing their longer-term dependency on } \\
\text { benefits. }\end{array}$ \\
\hline Programme launch & 2011 & 2012 \\
\hline Size (participants referred) & $\begin{array}{l}128,237 \text { people aged } 18-24 \text { were attached to } \\
\text { the scheme in the 'early access' (IF equivalent) } \\
\text { group up to March } 2017\end{array}$ & 18,300 in total \\
\hline $\begin{array}{l}\text { Eligible participants, as specified } \\
\text { by DWP }\end{array}$ & $\begin{array}{l}\text { All long-term unemployed people (or those } \\
\text { deemed at risk) who are in receipt of out-of- } \\
\text { work benefits. The 'early access' group } \\
\text { includes young people aged } 18 \text { who are } \\
\text { 'NEET' and those who are identified by work } \\
\text { coaches to be at particular risk of long-term } \\
\text { unemployment, such as care-leavers aged } 18- \\
21 .\end{array}$ & Disadvantaged young people aged 14 - 24 \\
\hline Provider organisations & $\begin{array}{l}\text { Prime contract holders are predominantly large } \\
\text { (>£20m annual turnover) private sector } \\
\text { organisations but the supply chain of providers } \\
\text { includes both VCSE and private sector } \\
\text { organisations }\end{array}$ & $\begin{array}{l}\text { Service providers are predominantly VCSEs } \\
\text { with working capital provided by 'social } \\
\text { investors' }\end{array}$ \\
\hline Procedural accountabilities & $\begin{array}{l}\text { Fixed, mandatory referral process for the } \\
\text { majority of programme participants overseen } \\
\text { by the Public Employment Service 'Jobcentre } \\
\text { Plus'; weakly defined 'Minimum Service } \\
\text { Guarantees' }\end{array}$ & $\begin{array}{l}\text { No fixed rules for participation; no stipulated } \\
\text { service expectations beyond adherence to } \\
\text { provider code of conduct }\end{array}$ \\
\hline Corporate accountabilities & $\begin{array}{l}\text { Contractual 'Minimum Performance Levels' } \\
\text { whereby providers risk losing contracts if the } \\
\text { ratio of job outcomes to programme starts dips } \\
\text { below specified levels }\end{array}$ & $\begin{array}{l}\text { No publicly available performance targets or } \\
\text { threat of termination in cases of under- } \\
\text { performance }\end{array}$ \\
\hline Market accountabilities & $\begin{array}{l}80 \%-100 \% \text { of payment to providers predicated } \\
\text { on 'sustained' job outcomes of } 13 \text { or } 26 \text { weeks } \\
\text { with subsequent monthly sustainment } \\
\text { payments. Differential payment system } \\
\text { intended to overcome creaming and parking }\end{array}$ & $\begin{array}{l}100 \% \text { of payment tied to a suite of payable } \\
\text { outcomes including improved school } \\
\text { attendance, behaviour, qualifications and } \\
\text { employment outcomes }\end{array}$ \\
\hline Democratic accountabilities & $\begin{array}{l}\text { Top down Ministerial responsibility; no choice } \\
\text { over provider; burdensome participant } \\
\text { complaints process via Independent Case } \\
\text { Examiner }\end{array}$ & $\begin{array}{l}\text { Participants attend voluntarily but feedback and } \\
\text { complaints processes are not clear in public } \\
\text { documents }\end{array}$ \\
\hline Network accountabilities & Merlin supply chain management & Not clear in public documents \\
\hline
\end{tabular}

Table 2: High-level programmatic comparison of the Work Programme and Innovation Fund

Within the Work Programme the market has been made in such a way as to attract large forprofit 'Prime' provider organisations, who contract directly with the DWP and who are then able to deliver services themselves and/or marshal and manage supply chains of smaller 
service providers, including the Voluntary, Community and Social Enterprise (VCSE) sector. The Programme adopts 'black box' commissioning whereby there are no mandatory service components and providers are "completely free to decide which interventions to offer to help participants into sustainable employment" (Lane et al. 2013, 11). A market-like system of $\mathrm{PbR}$ is the principal means through which to incentivise provider behavior. Since April 2014, the programme has been operating under 'pure' $\mathrm{PbR}$, as all payment to providers is now predicated on the measurable delivery of sustained employment outcomes (of at least 3- or 6months duration).

The DWP Innovation Fund SIB pilot is grounded in this shared set of marketization principles. This programme was set up in 2012 and uses a 100 per cent outcomes-based PbR model to support disadvantaged young people (aged 14 and over) who are either not in education, employment or training ('NEET' in the programme's lexicon) or who are identified as at risk of becoming so (DWP, n.d.). Under the Innovation Fund, the DWP set out a 'rate card', which establishes a menu of outcomes to which interventions are to be focused, and against which the DWP will make payments (HM Government, n.d.). In keeping with the Work Programme, service providers are afforded the 'freedom' to innovate and design flexible services. The public sector takes a position of agnosticism on the means of securing these outcomes and there is no prescription for minimum service components. Pairings of service providers and investors came forward in two rounds of procurement competition and DWP ultimately selected 10 individually-designed projects which were contracted as SIBs.

\section{SIBs and payment-by-results - a shared marketised logic and perennial concerns of 'gaming'}

On paper, both schemes operate according to the same fundamental marketised logic. An extreme form of $\mathrm{PbR}$ - where in both instances 100 percent of payments are now predicated on demonstrable social outcomes - is the key mechanism through which to steer service delivery of providers (Work Programme) or the investor-provider pairing (Innovation Fund). This highly marketised approach has been increasingly pursued by UK Government on the understanding that it can deliver a range of benefits including: improved cost effectiveness, innovation, accountability, systems-level planning, and responsiveness, with risk transferred to the private sector (NAO 2015).

These two employment support programmes have been laid down alongside a burgeoning international literature which suggests that there are perennial challenges to the achievement of equity and value-for-money within programmes which operate outsourced, lightly scrutinized PbR systems. Under such systems it is expected that economically 'rational' providers (and investors, in the case of SIBs) will respond to incentives by maximizing profits through 'gaming' practices in the programme signature, including:

- 'cherry picking' easier to support individuals from within a wider pool of those eligible i.e. behaving selectively pre-referral in situations where there is a rationing of programme places;

- 'creaming' participants who are closer to the labour market (post referral) and targeting services on them in the expectation that they are more likely to trigger an outcome payment (and that services required to facilitate this will be relatively lowcost) 
- 'parking' participants who are deemed unlikely and/or relatively expensive to generate outcome payments and who are therefore de-prioritised, receiving the minimum possible service (Rees et al., 2014).

The expanded use of outcomes-based contracts in public services has intensified concerns about their potential unintended effects (Koning and Heinrich, 2013). International literature also makes clear that the specificities of programme design and payment structures can play a key role in either facilitating or buttressing against such provider behaviours (Finn 2012). Crucially, the institutional setting and wider set of accountabilities informing stakeholder behaviours will interact with the potential for unintended practices such as cream skimming (Koning and Heinrich, 2013). While there are some obvious distinctions between the Work Programme and Innovation Fund, particularly in terms of scale and stakeholders involved, a critical deconstruction and appraisal of the schemes' alternative accountability dynamics garners insights as to the variation in scope-for and enactment-of gaming in practice.

\section{Method - comparative documentary analysis}

In order to investigate similarities and points of variation across the PbR schemes in relation to their accountability tools on paper and the lived experience of the respective programme 'signatures' for participants, this study draws on detailed documentary analysis of 'invitations to tender', DWP provider guidance and all official evaluation material related to the two programmes (commissioned by both DWP and by parliamentary scrutiny committees). The article takes these two schemes - which are implemented across the same time-frame; have overlap in participant characteristics; correspond in the type of service provider organisations; and where marketized logics of 'payment for outcomes' dominate - and uses detailed programmatic analysis to identify dominant accountability levers used to steer provider behaviours in each scheme. The evaluation material is used to surface the overriding 'signature' detectable in front-line interaction and participant experiences under each of the schemes.

It is important to note that despite considerable overlap in logics, priorities and participants, the Work Programme is a considerably larger, national programme. Consequently, a more sizeable body of research activity has been dedicated to the Work Programme. Although, both programmes have been subject to qualitative and quantitative evaluations, the quantitative impact evaluation for the Innovation Fund has yet to be published at the time of writing.

\section{Designing-in accountability levers to mitigate 'gaming'?}

The distinctions across the accountability levers of the two programmes can be unpacked by reflecting on the degree to which design specificities seek to mitigate the scope for gaming. This can be considered at three points across the programme implementation space: i) eligibility (corresponding to cherry picking), ii) service receipt (corresponding to creaming and parking) and iii) outcome specification (corresponding to a form of gaming behaviour made possible in scenarios where providers are paid for a range of 'outcomes' and where providers can shift focus across these).

Considering firstly the distinction in terms of cohort characteristics and referral processes, the Work Programme leans heavily on procedural accountabilities and has negligible scope for cherry picking since the assignment of participants is almost fully compulsory and referral to specific providers is through random allocation, overseen by Jobcentre Plus. Contrastingly, referral of participants to the Innovation Fund projects is highly ambiguous. Pre-tender, DWP 
set out a list of characteristics and traits which may indicate vulnerability or put young people at risk of poor outcomes (DWP, nd) but a high level of discretion on programme entry ultimately sits with provider agencies and there are no clear or definitive eligibility criteria. The evaluation material suggests that Innovation Fund Projects recruited a broad range of young people, with multiple risk factors and vulnerabilities (Griffiths et al., 2016).

Although the official Innovation Fund evaluation is robust in its suggestion that there was no gaming on referrals, despite the absence of defensive procedural accountabilities in this space, the evidence does require a more subtle reading, particularly in relation to the initial identification of participants. The original specification intended to address young people aged between 14 and 24, yet those projects which intended to work with older (16+) people who were already 'NEET' faced challenges in recruiting participants. Projects re-oriented provision towards school-aged pupils, who were "relatively easy to access and recruit" (Griffiths et al. 2016, 41). This is not explicitly framed as 'cherry picking' however, since younger participants were identified as at high risk of becoming 'NEET':

"School-aged participants ... had issues ranging from low educational attainment, poor selfesteem and self-confidence, motivational, emotional and behavioural difficulties, through to being in trouble with the police, to having chaotic or troubled home lives..."

Griffiths et al. 2016, 41

The decision to focus on younger participants then does not appear to have been a crude financial decision to target the 'easier' to help, but rather a more rounded approach to facilitate ongoing project implementation.

The next distinguishing aspect between the Work Programme and Innovation Fund is in designed accountabilities to mitigate the 'creaming' and 'parking' of assigned participants post-referral, during service delivery. The Work Programme includes procedural minimum service guarantees (MSGs) as a route to assure basic service standards for all. However, weaknesses in the substance, awareness and enforceability of the MSGs mean that in practice there is a strong reliance on the effectiveness of a marketised differential payment structure to defend against incentives to cream and park (Carter and Whitworth, 2015). Here participants are placed into one of nine claimant groups, based on the type of benefit received, as a proxy for the level of their perceived support needs. Job outcome fee values then vary such that higher fees are aligned with those in payment groups understood to be 'harder to help' (Lane et al. 2013).

Importantly, however, from the earliest stages of programme design, the Work Programme payment structure has been acknowledged as an overly crude basis on which to proxy distance to the labour market and, as a consequence, on which to calibrate groups and differential payment levels (WPSC 2013). There is growing and consistent evidence from within DWP's official evaluation (Newton et al. 2012; Meager et al. 2014), from parliamentary select committees (PAC 2013; WPSC 2013) and from academic research (Rees et al. 2014; Carter and Whitworth 2015) that the differential payment regime is not holding up in its ambition to guard against creaming and parking processes.

Providers in the Work Programme have developed profiling tools to 'triage' their caseloads and cream-skim those rated 'green', focusing energies on those easiest and most likely to move into work, whilst parking claimants rated 'red' who are considered to need more time and resource to support back into work (Rees et al. 2014). Such practices are understood to 
have been adopted by private sector and VCSE organisations alike, in response to the low overall level of funding available, the financial pressures resulting from discounting practices and the outcomes-based payment structure (Rees et al., 2013). The official programme evaluation commissioned directly by the DWP is peculiarly frank, noting, "the available evidence to date suggests that providers are engaging in creaming and parking, despite the differential payments regime" (Newton et al. 2012, 124).

In the Innovation Fund projects there is no recourse to procedural minima, 'rules' or standardized processes for participants. Aside from requirements to comply with DWP codes of conduct and ensuring the safety of young people who take part there is no service obligation for providers. The "Government believes that Delivery Bodies are best placed to understand what works to help individuals back to work. To achieve this, Delivery Bodies should have freedom to deliver in the most innovative way possible to achieve the best outcomes" (DWP, nd: 5). Under the Innovation Fund there are no explicit steering devices or incentives through which to ensure a bare minimum of services for harder-to-serve participants.

Somewhat surprisingly, given this unfettered scope to game by targeting resource at those participants most likely to achieve payable outcomes, with the neglect of those seen as unlikely to trigger payments, the evidence from Innovation Fund projects leans toward ruling out such practices. The qualitative material gives no indication that young people who were 'harder to help', or who were least likely to secure payable outcomes within the time available received a reduced form of support. Contrastingly, a number of projects reported that they had reached the maximum contract value (or were on target to do so) but "....were continuing to deliver support to their participants even though the cost of this delivery, having reached the payment 'cap', would reduce investment returns" (Griffiths et al. 2016, 28).

The final design distinction between the Work Programme and Innovation Fund projects relates to the spread of payable outcomes within each scheme. The Innovation Fund rate card - when set against the payment schedule for the Work Programme, which only rewards sustained employment outcomes - clearly offers a more subtle and varied set of social 'outcomes'. For a programme geared to securing employment, the school-based outcomes in particular appear more as 'milestones' or interim payments. The highest fees are associated with higher-level qualifications and employment outcomes and the intermediate outcomes in the Innovation Fund can be seen as an analogue to the automatic 'attachment fees' paid in early years of Work Programme implementation since both serve to reduce risk and smooth cash flow.

This flexibility to pursue payment across a suite of 'outcomes' introduces the possibility of other gaming activities that could occur in the implementation of Innovation Fund projects. At the procurement stage SIB-providers tendered for numbers of outcomes at specified unit prices. The Rate Card set out the maximum unit prices that DWP was willing to pay and SIB providers are understood to have bid under these costs. A maximum PbR liability or 'contract cap' was then constructed for winning providers by multiplying the tendered numbers of outcomes by their respective unit prices. During delivery, however, providers were able to deliver and be paid for outcomes more flexibly. For example, provided that they had not hit the overall contract cap, payment for over-performance on particular outcomes was not capped, so higher achievement for some outcomes could compensate for lower achievement on others. 
Currently there is limited available evidence to consider whether Innovation Fund projects focused their efforts to the achievement of near-term payable outcomes. In relation to the targeting of effort to payable outcomes (rather than other outcomes that may have been more meaningful to young people) the stakeholder interviews reveal that investors endorsed decisions to encourage some young people to stay on at school or undertake voluntary work, when this was seen as the best option for them, "even though no funded outcome would likely be achievable or claimable within the timeframe of the project by this route" (Griffiths et al. 2016, 28).

\section{Variation in the scope for gaming}

There is clear and considerable variation across the accountability levers that are explicitly (through eligibility rules, contractual service minima; payment groups) applied in each of the programmes. Consequently, there is variation in the degree to which there is scope for perverse practices within programme implementation. The proclivities for gaming within high powered $\mathrm{PbR}$ schemes was clearly acknowledged by architects of the Work Programme and at each stage of potential gaming, very clear attempts have been made to configure accountability levers (principally through further marketised tools around pricing) to cut against these tendencies. The scope for gaming opportunities within the Innovation Fund is markedly broader, since the scheme is prone not only to creaming and parking, but also to cherry picking and arguably also to selectivity across the configuration of payable outcomes. There is no punishment or incentive to mitigate a slide towards 'easier to achieve' outcomes within the rate card. Arguably, under the Innovation Fund, there is an accountability gap with very little by way of conventional accountability devices of rules and requirements (procedural); targets for particular user groups or characteristics (corporate); finely tuned financial incentives (market); or user voice/complaints procedures (democratic) through which these perverse incentives might be mitigated. What is striking then is the way that the evaluation material suggests that such cynical behaviours are not prevalent in practice.

What becomes clear - acknowledging that the volume of Innovation Fund evidence is considerably smaller - is that while the Work Programme treads down heavily in terms of creaming and parking practices, leaving deep evidence of the dominance of marketised accountabilities, this is absent (or assuredly less detected) in the application of Innovation Fund projects, despite the wider scope for such practices to occur. The 'signature' of a marketised accountability regime is absent.

The question then is how or why the 'inevitable' tendencies towards gaming associated with marketised accountabilities have been overcome or otherwise dissipated within the Innovation Fund. Unlike the Work Programme's hubristic differentiated payment model, the Innovation Fund contained within it no specific design features intended to counter gaming. The absence of creaming and parking in the footprint of this programme then does not appear to be the outcome of a conscientious and deliberate policy design effort. It is pertinent then to look for other ways in which tendencies to cream and park may have been softened within the Innovation Fund.

\section{Varying stakeholder motivations - the importance of the social imperative}

This brings us to the final, and conceptually most important difference between the two programmes: the social-motivations of stakeholders and the formalised distinction between 
investors and providers. The Work Programme operates under a Prime provider model whereby the DWP only contracts with large 'Prime' providers, who in turn manage a supply chain of sub-providers. These Prime providers were required to demonstrate an annual turnover of at least $£ 20$ million as an indication of ability to carry the financial risk associated with the back-ended nature of the PbR contract (DWP 2010). The profile of Prime contract holders in the Work Programme is dominated by large, for-profit, international service provider organisations who then subcontract but who are not required to make working capital available for VCSE sub-contractors to handle the pressures of outcomes contracts. Innovation Fund projects, by contrast are delivered by 'pairings' of smaller, usually VCSE organisations and independent investors. The application process stipulated that the investor be a legally separate entity from the delivery agency and that some or all of the financial risk of non-delivery of outcomes sits with the investor (DWP n.d.).

The characteristics and behaviours of the SIB stakeholders themselves appear to carry some relevance. Under a marketised logic each party to the SIB has a very clear 'textbook' role defined in relation to their position in terms of capital flows. Social Investors provide upfront funding for service delivery costs and seek to protect their investment and boost returns, service providers deliver interventions intended to deliver the best possible social outcomes and commissioners commit to pay for prescribed social outcomes. What we see in practice, however, for each of these parties, is considerable stretch beyond what is stipulated in their textbook function.

Investors have had a great deal of direct and 'hands on' involvement in Innovation Fund projects, but this is not in sole pursuit of financial returns (Griffiths et al. 2016). SIB investors need to have a substantial capacity for loss, be highly patient and may also accept higher risk and lower returns than in conventional investment (Worthstone, 2013). Importantly then, these are unusual investors, motivated by the opportunity to improve social outcomes. UK SIBs, in contrast both with the financing of mainstream UK PbR arrangements and with SIBs pursued in the US and Australia, are dominated by investment flowing from the socially motivated end of the investor spectrum, with charitable foundations and 'impact investors' dominating the SIB landscape ${ }^{i}$. What the evaluation material begins to suggest is that it is the social intent that enables investors to stretch beyond their conventional return-protecting function and reach into a position of pursuing stronger social outcomes.

As with SIBs more broadly, the VCSE service providers have not crudely positioned themselves to cynically maximise the delivery of payable social outcomes but engage in pursuit of their mission. Moreover, because of the separation of investor and provider roles within the SIBs, these organisations are largely, if not totally, shielded from the imperative of financial risk. A recent OECD synthesis (2016) similarly identifies the absence of discernible creaming and parking practices and speculates that this may be related to the strong social ethos of dedicated social enterprise service providers, yet it is not possible to conclude whether the absence of creaming and parking "is the result of 'good' organisations delivering the service or an intrinsic aspect of the way that these contract results were specified" (OECD, 2016:16). Given that there is very little by way of contractual design that explicitly defends against practices of gaming in the Innovation Fund gives credence to the importance of social motivations and trust-based (rather than purely marketised) accountabilities.

Importantly, the absence of designed accountability structures to mitigate cynical gaming practices implicitly leaves SIB arrangements reliant on some innate 'goodness' of the provider organisations or 'trustworthiness' within the contractual arrangement to counteract 
these proclivities. Descriptions of how policymakers mobilise around a simplified voluntary sector ideal - which ascribes VCSE organisations with a number of distinctive positive characteristics (value-driven, personalised and responsive to service users) - emphasise a degree of naivety in a perspective that marks a crisp boundary between the voluntary and private sectors (Heins and Bennett, 2016). Studies of VCSE organisations delivering public services have suggested that these organisations respond to the pressures of operating within marketised governance systems and may undergo significant transformations over time (Heins and Bennett, 2016; Aiken and Bode, 2009). Such findings would infer a need for caution in a reliance on innate voluntary sector values as the alleged strengths and distinctiveness of such organisations may be eroded within marketised systems.

\section{A space for network accountabilities?}

In terms of network accountabilities, the intention for Work Programme providers to collaborate and work in synthesis with relevant local agencies and with their supply chains was written into the invitation to tender document (DWP, 2010). In practice, this has been a toothless recommendation: despite the Merlin standard for supply chain management Prime providers have starved smaller sub-prime organisations of referrals and of income flows (Meager et al., 2014). The disputes and challenges between smaller service providers and overarching Prime contract holders have been well documented by voluntary sector representatives (Rees et al., 2013).

Under the Innovation Fund, although service provider experiences have not been universally positive (Edmiston and Nicholls, 2018) and the involvement of investors with associated high levels of management information and performance scrutiny has been something of a culture shock, partners were "pleasantly surprised" by the shared investor commitment to securing good social returns (Griffiths et al. 2016, 28). Investors did seek to ensure that projects did not fail financially, but beyond this gave "priority to measures that would maximise the social impact and benefit to young people even where this entailed making decisions that would likely reduce the financial rate of return achieved" (Griffiths et al. 2016, 11).

Importantly, the evaluation of Innovation Fund projects was not constructed explicitly to investigate accountabilities. Nevertheless, the qualitative research gives important indications as to the cooperation between stakeholders. The pursuit of social outcomes within Innovation Fund projects can be understood as a shared endeavour (principally as a cooperative effort between investor-provider pairings but also through coordination with schools and other stakeholders who are not the immediate financial beneficiaries of the service) based on relationships of trust. Notably, even when projects were not performing as anticipated "investors went to considerable lengths to support and capacity build providers that were struggling to generate sufficient outcomes for financial viability, although the risk of incurring losses was clearly high" (Griffiths et al., 2016, 28).

\section{Conclusions}

Within the Innovation Fund SIBs it does not seem appropriate to describe accountabilities purely as a highly marketsied form. These projects appear to lack the signature targeting of services to those who are most likely to achieve 'payable outcomes' commonly associated with marketised accountabilities. What binds and steers behaviours - the systems of 
knowing, evaluating and responding to agent actions - appears closer to a market-network hybrid. The accountabilities within these SIB projects are not captured as market-dominated $\mathrm{PbR}$ contracts but rather as a shared project for the pursuit of social outcomes with codependencies between stakeholders. Trust-led, relational 'network' governance begins to emerge as a distinguishing, and arguably crucial, differentiator of SIBs.

This conclusion, albeit tentative (since it is based on a currently limited evidence base relating to the governance of SIB programmes) has important implications for those considering the scaling of SIBs and their application internationally. The UK social investment strategy has set out an ambition "to have a SIBs market worth more than $£ 1$ billion by the end of this Parliament [2020]" (HM Government 2016). To proactively grow the market to this scale it is likely that policymakers will pursue both more and larger SIBs. This is likely to have an impact on the close working relationships between those involved and also on the complexion of investors. The longer-term implications of the application of SIBs; the terms on which capital is drawn into PbR programmes; and the variation in governance structures experienced across outcome-led approaches therefore sit as important areas of future research.

In the comparison of the Work Programme and the Innovation Fund it appears that the hybridity of accountabilities within SIB structures has occurred by happenstance rather than explicit policy design. Collaboration, trust-based working and the social motivations of SIB stakeholders emerge as potential differentiators of this approach. A consideration of these facets will be critical in developing our understanding of whether and how SIBs offer the opportunity to step beyond the limitations of highly-marketised accountability arrangements. Practitioners will need to be alert to whether it is possible, or desirable, to extend the size and reach of the SIB mechanism or whether increased scale and involvement of mainstream investors will dilute the 'SIB effect'.

\section{References}

Aiken, A. and Bode, I. 2009. "Killing the Golden Goose? Third Sector Organizations and Back-to-Work Programmes in Germany and the UK" Social Policy and Administration. 43, 3, 209-225.

Bovaird, T. and Davies, R. 2011. "Outcome-based service commissioning and deliverydoes it make a difference?" In New Steering Mechanisms in Public Management (Research in Public Policy Analysis and Management, Volume 21), edited by Groeneveld, S. and van de Walle, S. 93-114. Bingley: Emerald.

Bovaird, T., and Löffler, E. 2009. Public Management and Governance, Second Edition. Abingdon: Taylor \& Francis.

Carter, E., FitzGerald, C., Dixon, R., Economy, C., Hameed, T., and Airoldi, M. 2018 Building the tools for public services to secure better outcomes: Collaboration, Prevention, Innovation. Government Outcomes Lab, University of Oxford, Blavatnik School of Government. 
Carter, E. and Whitworth, A. 2015. "Creaming and Parking in Quasi-Marketised Welfare-toWork Schemes: Designed Out Of or Designed In to the UK Work Programme?" Journal of Social Policy 44(2): 277-296.

Considine, M. 2001. Enterprising States: The Public Management of Welfare-to-Work. Cambridge: Cambridge University Press.

de Graaf, W. and Sirovatka, T. 2012. "Governance reforms and their impacts on the effects of activation policies." International Journal of Sociology and Social Policy, 32 (5/6): 353-63. doi:10.1108/01443331211236943.

Department for Work and Pensions (DWP) No Date. The Innovation Fund Invitation to Tender Specification and Supporting Information. London: Department for Work and Pensions.

Department for Work and Pensions (DWP). 2010. The Work Programme: Invitation to Tender. London: Department for Work and Pensions.

Department for Work and Pensions (DWP). 2016. Youth Unemployment Innovation Fund pilot: starts and outcomes to Sept 2015. Accessed March 30 2017:

https://www.gov.uk/government/statistics/youth-unemployment-innovation-fund-pilot-startsand-outcomes-to-sept-2015

Department for Work and Pensions (DWP). 2017. Quarterly Work Programme National Statistics to September 2016. Accessed March 30 2017:

https://www.gov.uk/government/statistics/work-programme-statistical-summary-data-toseptember-2016

Doherty, B., Haugh, H. and Lyon, F. 2014. "Social Enterprises as Hybrid Organizations" A Review and Research Agenda" International Journal of Management Reviews, 16, 417-436.

Dowling, E. and Harvie, D. 2014. "Harnessing the social: State, crisis and (big) society." Sociology, 48 (5): 869-86. Doi 10.1177/0038038514539060.

Edmiston, D., \& Nicholls, A. (2018). Social Impact Bonds: The Role of Private Capital in Outcome-Based Commissioning. Journal of Social Policy, 47(1), 57-76. doi: $10.1017 /$ S0047279417000125

Finn, D. 2012. Sub-Contracting In Public Employment Services: The Design and Delivery of Outcome Based and Black Box Contracts, DG Employment, Social Affairs and Inclusion, European Commission. Accessed March 302017.

http://ec.europa.eu/social/main.jsp?catId=964.

Fraser, A., Tan, S., Lagarde, M. and Mays, N. 2016. "Narratives of Promise, Narratives of Caution: A Review of the Literature on Social Impact Bonds." Social Policy and Administration, doi: 10.1111/spol.12260.

Gingrich, J. 2011. Making Markets in the Welfare State: The Politics of Varying Market Reforms, Cambridge, UK: Cambridge University Press. 
Hirschman, A. 1970. Exit, voice and loyalty. Cambridge, MA: Harvard University Press.

Griffiths, R., Thomas, A. and Pemberton, A. 2016. Qualitative Evaluation of the DWP Innovation Fund: Final report. Research Report No 92. London: Department for Work and Pensions.

Gustafsson-Wright, E., Gardiner, S., Putcha, V. 2015. The Potential and Limitations of Impact Bonds: Lessons from the first five years of experience worldwide, Washington, DC: Brookings.

Heins, E. and Bennett, H. 2016. ' Best of Both Worlds'? A Comparison of Third Sector Providers in Health Care and Welfare-to-Work Markets in Britain'. Social Policy and Administration, 50, 1: 39-58.

HM Government. 2016. Social investment: a force for social change 2016 strategy. London: Cabinet Office.

HM Government. Nd "Innovation Fund Key facts". Accessed December 10 2017: https://assets.publishing.service.gov.uk/government/uploads/system/uploads/attachment_data /file/212328/hmg_g8 factsheet.pdf

Jantz, B. Klenk, T. Larsen, F. and Wiggan, J. 2015 "Marketization and Varieties of Accountability Relationships in Employment Services Comparing Denmark, Germany, and Great Britain.” Administration \& Society1-25. DOI: 10.1177/0095399715581622.

Lane, P., Foster, R., Gardiner, L., Lanceley, L. and Purvis, A. 2013. Work Programme Evaluation: Procurement, Supply Chains and Implementation of the Commissioning Model, London: Department for Work and Pensions.

Meager, N., Newton, B., Sainsbury, R., Corden, A. and Irvine, A. 2014 Work Programme Evaluation: The Participant Experience Report. London: Department for Work and Pensions.

National Audit Office (NAO). 2015. Outcome-based payment schemes: government's use of payment by results. London: NAO Communications.

Newton, B., Meager, N., Bertram, C., Corden, A., George, A., Lalani, M., Metcalf, H., Rolfe, H., Sainsbury, R. and Weston, K. 2012. Work Programme Evaluation: Findings from the First Phase of Qualitative Research on Programme Delivery. London: Department for Work and Pensions.

OECD, 2016. Social Impact Bonds: State of Play and Lessons Learnt. OECD Publishing.

Public Accounts Committee (PAC). 2013 Department for Work and Pensions: Work Programme Outcome Statistics, Thirty-third report of session 2012-13. London: The Stationery Office.

Rees, J., Taylor, R. and Damm, C. 2013. "Does Sector Matter: The Role of the Third Sector in the Work Programme." Third Sector Research Centre Working Paper No. 92, University of Birmingham: Third Sector Research Centre. 
Rees, J., Whitworth, A. and Carter, E. 2014. "Support for all in the UK Work Programme? Differential payments, same old problem." Social Policy and Administration. 48: 221-239, doi: 10.1111/spol.12058.

Roberts, T. 2013. The Centre for Social Impact Bonds. Civil Service Quarterly. Issue2. 27 30 , Accessed March 302017.

https://www.gov.uk/government/uploads/system/uploads/attachment_data/file/251799/Civil Service_Quarterly_Issue2.pdf

Thomas, A. and Griffiths, R. 2014. The Innovation Fund pilots: qualitative evaluation: early implementation findings. London: Department for Work and Pensions.

Warner, M. E. 2013. "Private finance for public goods: Social impact bonds." Journal of Economic Policy Reform, 16(4): 303-19. DOI: 10.1080/17487870.2013.835727.

Whitworth, A. and Carter, E. 2017. "Rescaling employment support accountability: from negative national neoliberalism to positively integrated city-region ecosystems?"

Environment and Planning $C$.

Wiggan, J. 2015. "Varieties of marketisation in the UK: examining divergence in activation markets between Great Britain and Northern Ireland 2008-2014." Policy Studies, 36(2): 115 - 132. DOI: 10.1080/01442872.2014.996934.

Work and Pensions Select Committee (WPSC). 2013. Can the Work Programme Work for All User Groups? First Report of Session 2013-14. House of Commons, London: The Stationery Office.

Worthstone. 2013. Social Impact VCT plc: Financial Planner Summary and Analysis. Accessed 30 March 2017: http://www.worthstone.co.uk/adviserarea/assets/pdfs/Worthstone_ProductReview_VCT.pdf

\footnotetext{
${ }^{\mathrm{i}}$ See investors in UK SIBs listed here: https://golab.bsg.ox.ac.uk/knowledge/project-database/
} 